\title{
REPRESSÃO, RETÓRICA E PODER - AS MULHERES, OS CLÉRIGOS E A FOGUEIRA: UMA LEITURA SEMIOLÓGICA DA PROTAGONISTA BRANCA DIAS DE O SANTO INQUÉRITO, DE DIAS GOMES
}

\author{
Francisco de Souza Gonçalves ${ }^{1}$
}

RESUMO: O presente artigo visa a analisar os semas de Branca Dias, personagem emblemática de $O$ Santo Inquérito, obra prima do dramaturgo Dias Gomes. A semiologia, isto é, estudo do sema é uma nova forma de leitura do teatro, modalidade que, no século XX, teve sua perspectiva modernizada e modificada, juntamente com todos os campos da arte. Os feixes sígnicos apresentam-se como utilíssimas ferramentas para uma visão mais global da arte dramatúrgica: aqui, o aprofundamento investigativo dar-se-á nos signos constitutivos de Branca Dias e daqueles que a circundam, pesquisando como essa interação nos fornece um panorama de "repressão" ao feminino jacente na obra. Polêmica, a obra de Gomes nos evoca não só a Inquisição européia de fins da Idade Média, mas também o contexto em que foi escrita: a ditadura militar brasileira. É uma pesquisa conjugada de texto (discurso), contexto (histórico, sócio-político), rubrica, constituição das personagens insertas na trama, enredo e outros elementos que, conjugados, promovem a ação dramatúrgica, o fim último do texto teatral.

Palavras-Chave: repressão, teatro, personagens femininas, literatura brasileira.

ABSTRACT: This article aims to analyze the semas of Branca Dias, emblematic figure of $O$ Santo Inquérito, masterpiece of playwright Dias Gomes. Semiology, the study of the sema is a new way of reading the theater, a modality that, in the twentieth century, has your perspective changed and modernized, with all fields of art. Signic beams appear as extremely helpful tools for a more global view of the dramaturgical art: here, the depth investigative give the signs will constitute Branca Dias and those surrounding it, in researching how this interaction provides an overview of "repression "in abeyance the feminine work. Controversial, the work of Gomes evokes not only the Inquisition of the late European Middle Ages, but also the context in which it was written: the Brazilian military dictatorship. It is a combined search text (speech), context (historical, socio-political), heading up the inserts characters in the plot, plot and other elements which, combined, promote dramaturgical action, the ultimate end of the theatrical text.

Keywords: repression, theatre, women characters, Brazilian Literature.

Há um mínimo de dignidade que o homem não pode negociar, nem mesmo em troca da liberdade. Nem mesmo em troca do sol ${ }^{2}$.

A personagem pode ser a metáfora de muitas ordens de realidade ${ }^{3}$.

\footnotetext{
${ }^{1}$ Doutorando em Literatura Comparada no Programa de Pós Graduação em Letras da Universidade do Estado do Rio de Janeiro (UERJ); mestre em Letras - Literatura Portuguesa, na supramencionada IES; Professor Docente da SEEDUC-RJ e membro da Associação Brasileira de Estudos Medievais (ABREM). Email: sg.francisco@gmail.com.

2 GOMES, Dias: 1985 ; p. 140 in O Santo Inquérito (fala da personagem Branca Dias).
} 


\section{Preâmbulos}

O presente estudo propõe uma discussão sobre os semas, isto é, sinais, que constituem a protagonista Branca Dias, de O Santo Inquérito, de Dias Gomes. Munido do fito basilar de promover tal investigação, pretende-se lançar mão dos signos que Gomes fornece ao expectador/ leitor ao longo da ação dramática/ narrativa. Além de uma abordagem dos semas, signos, constituintes da persona de Branca Dias dentro do cosmo ficcional de Dias Gomes, pretende-se promover o cotejo do folclore que envolve a personagem provinda do imaginário popular paraibano. Esses elementos folclóricos conjugar-se-iam com outros, impressos pelo toque da pena de Gomes, trazendo à tona uma Branca Dias totalmente singular, de uma inteireza única. Pretende-se, ainda, contextualizar a personagem no tempo em que a narrativa se passa e na época em que foi composta. A metodologia é comparativa e a pesquisa bibliográfica, com premissas hipotético-dedutivas.

O Santo Inquérito é uma peça que tem o seu desenrolar na Paraíba do século XVIII, mais precisamente em 1750. Foi composta por Dias Gomes e encenada pela primeira vez em 1966, em pleno regime militar brasileiro.

Conta-se a história de Branca Dias, uma jovem aparentemente simples, que um dia, ao ver um homem se afogando em um rio, salva-o da morte, através de suas habilidades como nadadora e de respiração boca a boca. Este homem, Padre Bernardo, é um jesuíta.

Branca Dias vive com seu pai Simão Dias e é uma jovem de um vivaz fulgor pela vida, apaixonada por seu noivo Augusto. Sua familia é de cristãos novos, isto é, judeus obrigados a converter-se ao cristianismo, pelo Tribunal do Santo Ofício, órgão responsável por uma conservação da fé católica a qualquer preço. Os judeus eram obrigados a converterem-se, os que não o fizessem eram abandonados ao braço secular, isto é, entregues à justiça secular para que fossem presos, expatriados e, mais comumente, executados.

Assim, ao salvar Padre Bernardo, Branca cria laços de amizade com o jesuíta, fazendo dele o seu confessor. Este, imbuído do aparente compromisso

\footnotetext{
${ }^{3}$ UBERSFELD, Anne: 2005; p.78 in Para Ler o Teatro.
} 
obsessivo de salvar a alma da moça, lança-se num batel de imprecações contra os atos da mesma. A simplicidade da protagonista deixa-se levar pela suposta "autoridade eclesiástica" da qual o Padre é representante. Seu mundo, antes simplório, radiante, torna-se um redemoinho de atos de penitência, em que tudo passa a ser condenável e pecaminoso; todos os atos da jovem passam a ser considerados como uma ofensa ao divino.

A partir dessa relação íntima com Padre Bernardo, uma série de acontecimentos é desencadeada, culminando com a morte de Augusto e Branca, nos famosos autos de fé inquisitoriais. Simão Dias se salva abjurando; isto é, declarando-se culpado por qualquer ofensa ao "deus" ali preconizado, qualquer prática de judaísmo e heresia contra a Instituição Católica. O pai de Branca cede às invectivas da Inquisiçao, representando uma entrega de qualquer ideal libertário que pudesse possuir, corroborando, pelo seu ato, o sistema vigente, repressor e cruel.

Branca e Augusto morrem por não cederem aos desejos do Santo Ofício de declarar qualquer culpa que não possuíam. Representam o ideal de liberdade que se imola em nome da honra do ser humano e de sua dignidade.

Toda a ação se desenrola durante o julgamento de Branca num esquema de flash-back e sobreposição psicológica os fatos vão sendo mostrados. O esquema é ternário sendo o elemento desestabilizador da trama dramatúrgica o salvamento de Padre Bernardo por Branca. A peça teatral, apesar de sua construção mimética, reflete, perfeitamente, as propostas de desconstrução, emergentes no século XX, com um desenrolar diametralmente oposto ao esquema provindo do teatro romântico ou do teatro clássico. Deste último, há o uso do coro, o que remete às peças clássicas.

\section{Relações texto/contexto em $O$ Santo Inquérito}

Neste tópico do estudo, pretende-se analisar e levantar dados que auxiliem um melhor entendimento da personagem de Branca Dias, tanto do ponto de vista diegético quanto do extradiegético. Leva-se em conta o contexto histórico o em que a obra dramatúrgica foi composta, e que qual é a época em que ação se desenrola. 
Desde o início dos anos 60, o Brasil passava por drásticas mudanças no campo sócio-político. A maior delas foi o Golpe Militar de 1964, que fixava definitivamente o conservadorismo de direita no poder. Um governo autoritário e repressivo se fixa no mais alto posto de poder da nação: o General Castello Branco tornava-se presidente.

Os soldados armados de fuzis prendiam milhares de pessoas: dirigentes populares, intelectuais, políticos democratas. $A \mathrm{UNE}^{4}$ foi proibida e seu prédio, incendiado. A CGT, fechada. Sindicatos invadidos à bala. Nas escolas e universidades, professores e alunos progressistas expulsos. Os jornais foram ocupados por censores e muitos jornalistas postos na cadeia. A ordem era calar a boca de qualquer oposição. (SCHMIDT, 1997, p.328/329)

Em nossa abordagem, podemos notar de forma bem pronunciada que Gomes evoca uma realidade passada para promover uma visão crítica do período em que estava inserto. A sua crítica se dirige, diretamente, aos generais do regime militar instalado no Brasil desde o golpe militar. Essa situação de repressão, apoiada por uma parte da população, que se não corroborava com os militares do regime opressivo, era marcada pela passividade ou não reação, acabando por constituir um apoio ao poder vigente, levada pela implantação de um injustificável medo do "comunismo": "No Rio de Janeiro - Copacabana, Ipanema -, a classe média confraternizava com a burguesia (...) Abraços, choro de alegria, alívio pelo fim da desordem. O Brasil estava salvo do comunismo!" (SCHMIDT, 1997, p.328)

Muitos foram os heróis e lutadores da liberdade que surgiram nesse período, todos eles, discordantes da realidade que se impusera, foram mortos, exilados e duramente punidos pelo regime violento, aparelho repressor da Ditadura Militar. Como Branca Dias e Augusto Coutinho se sacrificaram em nome de um ideal maior, a liberdade de ação e pensamento.

Uma forte arma de resistência contra a falta de liberdade foi a Dramaturgia. Desde a década de 40 , a prática de um teatro ligado ao engajamento político se instala no Brasil, como uma artilharia escamoteada visando a apregoar idéias interditadas pela censura do regime vigente. Importante é a colocação do historiador Mario Schmidt (1997, p.318) sobre o tema:

\footnotetext{
4 "União Nacional dos Estudantes"
} 
A primeira grande mudança do teatro brasileiro veio com a fundação do TBC $^{5}$ em São Paulo (1948), revelando jovens atores como Paulo Autran, Cacilda Becker, Sérgio Cardoso, Fernanda Montenegro. A renovação da linguagem teatral brasileira já vinha acontecendo desde 1943, quando o pernambucano Nélson Rodrigues (1912-1980) lançou Vestido de Noiva. (...) Nos anos 60, o TBC foi acusado de se prender a peças estrangeiras (...). Contra isso, surgem, em São Paulo, as cias. teatrais "Teatro de Arena" e "Teatro Oficina". [A voga de então] eram as peças do alemão Bertolt Brecht (1898-1956), que defendia um teatro de distanciamento dialético, ou seja, que em vez de iludir o espectador [entreter] com a encenação, o levasse a refletir sobre a peça e a realidade em que vive. Autores estrangeiros como Sartre, Górki e Tennessee Williams foram encenados junto com brasileiros como Dias Gomes, Gianfrancesco Guarnieri, Oduvaldo Viana Filho, Augusto Boal ${ }^{6}$, Ariano Suassuna. (GRIFO NOSSO)

Dentre essas peças encenadas, as tragédias e peças com o tema da liberdade foram muito caras à resistência promovida pela arte ante os sistemas repressores em plena vigência: tais peças clássicas, de forte característica mimética apareciam como veiculadoras metáforas postuladoras de "idéias subversivas". "O Santo Inquérito" traz em seu bojo esta forte carga de luta política, como pode ser constatado pela citação do autor da peça entre os acima relacionados. Assim, reitera-se a função libertária da cultura nesses tempos:

\begin{abstract}
De 1964 a 1968 a cultura brasileira viu o surgimento de novos valores, que direta ou indiretamente anunciavam uma certa contestação ao acontecia no país e no mundo. A censura ainda aceitava algumas brechas (ela se tornou mais feroz a partir do final de 1968). O teatro foi claramente de protesto, buscando conscientizar (...) o público através de choques culturais ("quebrar os tabus", "romper com as normas sociais" [...]) usando recursos como palavrões, nudez (...), cenário caótico, falas e gestos agressivos ou com sentido vago e uma temática abertamente politizada. $O$ diretor José Celso Martínez, do grupo "Teatro Oficina" (SP), o grupo do "Teatro de Arena" (RJ), que projetou Dina Sfat e Paulo José, autores Oduvaldo Viana Filho, Plínio Marcos, Augusto Boal e João Cabral de Mello Neto (Morte e Vida Severina) marcaram época. (SCHMIDT, 1997, p.331) (GRIFO NOSSO)
\end{abstract}

Em ambos os casos, Inquisição e Golpe Militar de 64, incorrem na força inibidora de liberdade que, por certas vezes, toma alguns grupos humanos. Esse "link" entre duas realidades fica patente na primeira rubrica da peça:

\footnotetext{
5 "Teatro Brasileiro de Comédia"

6Gande teatrólogo brasileiro funda dor do "Teatro do Oprimido", suas idéias inovadoras e singulares o levarama ser estudado em inúmeros países como um dos insignes ícones do teatro contemporâneo.
} 


\begin{abstract}
Ouve-se o ruído de soldados marchando. A princípio, dois ou três, depois quatro, cinco, um pelotão. Soa uma sirene de viatura policial, cujo volume vai aumentando, juntamente com a marcha, até chegar ao máximo. Ouvem-se vozes de comando confusas, que também crescem com os outros ruídos até chegarem a um ponto máximo de saturação, quando cessa tudo, de súbito, e acendem-se as luzes. As personagens estão todas em cena: Branca, o Padre Bernardo, Augusto Coutinho, Simão Dias, o Visitador, o Notário e os guardas. (GOMES, 1996, p.31)
\end{abstract}

O encontro entre dois cosmos históricos distintos se dá de forma subreptícia, através do som da sirene e de feixes signatários que não nos remetem ao século XVIII, tempo narrativo, mas à contemporaneidade da encenação teatral. Dois universos se encontram para falar de uma situação que lhes é comum: a força repressora.

É necessário destacar nesta rubrica os fatores técnicos característicos à época referida, isto é, uma marca do teatro da década de 60/70: o uso de praticáveis e diferentes planos em detrimento de outros artifícios cenográficos, muito caros para as produções teatrais do período, esta é mais "rústica". Mostrando, além disso, por inserir tais indicações nas rubricas, a contemporaneidade e o entendimento profundo sobre o fazer teatral que Gomes possuía: "O palco contêm vários praticáveis, em diferentes planos. Não constituem propriamente um cenário, mas um dispositivo para a representação, que é completado por uma rotunda. É total a escuridão no palco e na platéia" (GOMES, 1996, p.31).

\title{
3. A Inquisição
}

Partamos para uma melhor compreensão do processo inquisitorial e a sua relação com o feminino, que é um dos principais leitmotivs de O Santo Inquérito. Segundo Hilário Franco Jr. (2006), a Organização da Inquisição se dá entre 1184-1229. No período medieval, ela é incipiente, todavia, já no Baixo Medievo este destacamento eclesiástico irrompe os limites de sua ação e se expande: "o processo misógino efetivado na Idade Média ganha força de lei por meio dos manuais de caça aos hereges" (MALEVAL, 2004, p.70). A figura do herege começa a se destacar e com isso, a imagem da bruxa, já formada e composta, construída no período medieval. Além disso, pretende-se 
contextualizar a obra dentro do período histórico-social em que está inserta, levando em conta a fortíssima ideologia clerical e as manifestações do grupo dos oratores ${ }^{7}$, a camada eclesiástica medieval.

A Gregório IX devemos a organização do tribunal inquisitorial e, em 1229, no Concílio de Toulouse, foi criado oficialmente o Tribunal do Santo Ofício. Os Dominicanos logo se puseram à disposição da nova instituição cabendo-Ihes a tarefa de legislar e condenar os heréticos, entregando-as ao braço secular. (...) mulheres, escravos ou crianças poderiam senvir como testemunhas de acusação, mas nunca da defesa (FALBEL, 2007, p.17).

Nos séculos $\mathrm{XV}$ e $\mathrm{XVI}$, o processo de construto de uma mentalidade misógina eclode no genocídio mundial, promovido pelo Tribunal da Santa Inquisição ou Tribunal do Santo Ofício. Tal Tribunal tinha por objetivo precípuo o combate de heresias e de hereges, tanto homens quanto mulheres: antes, o que era ameaça alienígena, com exceções aos movimentos do século XII (albigenses), torna-se uma "febre coletiva". Assim, apesar de "as bulas papais não fazerem distinção de gênero ao fomentarem a repressão, a maioria esmagadora dos réus era constituída por mulheres" (MALEVAL, 2004, p. 71). O feminino estigmatizado tornou-se o principal alvo, as mulheres tornaram-se a principal vítima das fogueiras inquisitórias.

A prática da feitiçaria ou magia, isto é, do que se delimita como práticas pagãs, e depois foram chamadas de bruxaria passa a ser a meta da repressão; o termo bruxaria implicaria relação direta com o demoníaco e penetraria ou o campo do satanismo ou do paganismo sincrético: superstições, sortilégios, ritos camponeses, etc.

Salienta-se que já na década de 1320, o papa João XXIl promulgou uma bula condenando a magia ritual, tomando-a por diabolismo e heresia. A seguir, buscar-se-á demonstrar, brevemente, a construção do estereótipo feminino do mal, numa tentativa de jungir história e literatura nesta investigação, sem contar que "a violência do braço secular contra a heresia parece ter crescido na proporção à sua difusão e influência" (FALBEL, 2007, p.16).

\footnotetext{
${ }^{7}$ Georges Duby expressa tal classificação como maneira de divis ão da sociedade de acordo com a função de cada estamento social dentro do imaginário medievo (DUBY, Georges. Guerreiros e Camponeses. Lisboa: Estampa, 1993. [p.181])
} 
Analisa-se, sucintamente, como a "sociedade teocêntricofundamentalista" medieval via a mulher e qual era o padrão comportamental instituído pelos clérigos para o sexo feminino neste período. Muito deste padrão, como será visto, deve-se, principalmente, à mentalidade teocêntrica, profundamente influenciada pelo legado patrístico e por heranças clássicas.

Durante a Idade Média, período embrionário da Inquisição, as questões concernentes à mulher foram objeto de numerosos didáticos, que abordavam, num campo de controvérsias, as virtudes e os defeitos femininos. Em linhas gerais, o padrão comportamental que regia a postura feminina ideal na época medieval era determinado pelos didáticos cristãos, visto que a lgreja ainda conservava boa parte do monopólio da escrita. Esses autores, baseados na interpretação das escrituras, vigente no medievo, ditavam as normas para o procedimento da mulher no âmbito social.

O eixo mais sólido do sistema de valores a que se fazia na casa nobre para conduzir-se, apoiava-se sobre este postulado fundado na Escritura: que as mulheres, mais fracas e mais inclinadas ao pecado, devem ser trazidas à rédea (DUBY, 1995, p.218)

O homem deveria ser o maior dentro da família e da sociedade, toda a organização institucional na Idade Medieval repousaria sobre a figura paterna, na célula familiar, a mulher e os filhos estariam sujeitos ao poder e domínio masculinos. Principalmente a esposa é quem deveria obedecer-lhe cegamente, "apesar de suas responsabilidades como dona de casa, em suas relações com o mundo as esposas estavam submetidas ao belprazer dos maridos" (Ibidem).

Filipe de Novare escreveu, em meados do século XIII, sobre os deveres da mulher e sobre os cuidados que sua educação exigiria. A primeira virtude a ser ensinada às meninas seria a obediência, pois a mulheres "foram feitas para obedecer": "Não convinha ao sexo frágil, saber ler ou escrever. Cabia à mulher aprender a fiar e a coser. A modéstia, o recato, a honestidade devem inspirar todas as ações da jovem" (idem, p.210). Eis, resumidamente, alguns dos mais importantes elementos que, segundo Novare, caracterizariam o tipo da mulher da mulher ideal da época.

Aborda-se aqui o âmbito familiar, pois este era o lugar a que se restringiria, segundo a norma dos didáticos medievais, o espaço onde a mulher 
poderia circular. Todavia, até mesmo neste espaço, sua liberdade era limitada. A mulher, nessa mentalidade, constituía "uma ameaça contra a ordem estabelecida", pois, conforme salienta Georges Duby, "o poder patriarcal sobre a feminilidade via-se reforçado, porque a feminilidade representava o perigo" (Idem, p.218). O autor ainda complementa:

No espaço doméstico, o perigo era principalmente percebido como vindo insidiosamente das mulheres, portadoras do veneno, dos sortilégios, da cizânia, e dos desfalecimentos, as doenças inesperadas, os falecimentos sem causa aparente (...). Tudo aparecia como artimanhas das mulheres, e da dama em primeiro lugar (Ibidem).

Reiteramos que tal visão, claramente dominada pela misoginia e opressão do feminino por parte dos homens e instituições, era tido como moralmente aceitável pelo clero, como uma norma de conduta a ser seguida, principalmente, pelas damas das classes mais altas, as nobres. Fala-se, aqui, no que era tido como padrão comportamental ideal pela ideologia da prelazia radical, e, não o que na prática, necessariamente, ocorria, pois tal ponto ainda apresenta controvérsias entre os historiadores. E, algumas mulheres, notórias, justamente por isso, desobedeciam a este padrão pré-estabelecido.

Paolo de Certaldo, moralista medieval, afirma:

A mulher é coisa vã e frívola (...). Se tens mulheres em casa, vigia-as de perto; dá freqüentemente uma volta por tua casa e, enquanto te dedicas às tuas ocupações, mantém-nas (essas mulheres) na apreensão e no temor (...) Que a mulher imite a Virgem Maria, que não saia de casa a tagarelar por todo lado, para trazer de olho os belos senhores e dar ouvidos às vaidades, não, ela permaneça encerrada, fechada, no segredo de uma casa como se deve (Idem, p.219).

Duby conclui o tópico aqui abordado, afirmando que "a sociedade doméstica era então atravessada por uma separação nítida entre o masculino e o feminino, institucional, e que repercutia sobre a maior parte dos comportamentos e das atitudes mentais" (Idem, p. 219).

Há uma importante dicotomia entre os sexos, enraizada na ideologia clerical, que também deve ser observada, influenciando, profundamente, 0 protótipo da bruxa desenvolvido entre os séculos XV e XVI. É a dicotomia que diz respeito à carne a ao espírito, cuja origem remonta crenças não só baseadas no patriarcalismo judaico, mas também nas teorias filosóficas da 
Grécia Antiga de desapego à sensualidade, aos sentidos (platonismo), rejeição à carne, e, principalmente uma sexização desta como feminina. Sendo o cristianismo também um herdeiro destas significativas influências culturais misóginas, observar-se-á que a nova religião as corrobora e inclui tais conceitos entre suas prescrições morais ao neófito. Rose Marie Muraro salienta:

O dualismo platônico mente/corpo, razão/emoção, que foi base de todo o pensamento ocidental nesses últimos três mil anos (...) serviu apenas como racionalização do exercício de poder expresso nas relações senhor/escravo, homem/mulher, opressor/oprimido, etc (MURARO, 2000, p. 39)

Assim, chegando ao período patrístico, poder-se-á observar uma cristalização da visão antagônica entre carne e espírito ligada ao gênero (MURARO, 2000): a misoginia do mundo helênico, mais mágica e fisiológica, passa a uma misoginia teologizada no cristianismo nascente (BLOCH, 1995). O homem seria o representante do espírito, da elevação através da razão, enquanto a mulher é, como na Antiguidade, ligada à carne, aos aspectos físicos e sexuais: a carne, passa aí, pelo processo de sexização: é feminina.

Com o Cristianismo, isso se agrava. A sexização da carne conduz a mais um fator causador de misoginia, que leva à configuração da mulher como a porta do diabo (ianua diaboli): o ascetismo, que ganhará grande voga nos inícios do cristianismo, principalmente através dos movimentos monacais, fomentará uma negação da carne e, por conseguinte uma exacerbação do antifeminismo. Muraro estabelece tal relação da seguinte forma: "a objetividade tem haver com o ascetismo, que vem por sua vez de uma negação do corpo e, portanto, da rejeição da mulher" (MURARO, 2000, p.45).

Todavia, o próprio cristianismo oferecerá novas contradições, já que afirma a superioridade dos "últimos" sobre os "primeiros", da "ovelha perdida" sobre o restante do "rebanho", do filho pródigo sobre o sédulo. O que se quer mostrar é que numa expressão antifeminista por excelência, que se dá obviamente através de assertivas preconceituosas dos primeiros Padres leva a uma nova relação antitética do feminino: o cristianismo imporá uma nova e confusa articulação entre os gêneros.

Com efeito, na medida em que a fragilidade da carne é remetida para o lado feminino, ela acarreta, através da inversão de valores de 


\begin{abstract}
fraqueza e força, sinônimos no catolicismo primitivo, a possibilidade de as mulheres serem mais fortes do que os homens (...). Portanto, as mulheres são consideradas candidatas especiais à salvação, uma vez que, de acordo com a dicotomia que coloca o homem do lado do espírito e a mulher do lado dos sentidos e da sedução, os homens, estritamente falando, têm menos a superar para serem redimidos (BLOCH, 1995, p. 38).
\end{abstract}

A mulher também será vista como a esposa de Cristo, aquela que pode ser fazer incrivelmente santa, suplantando todas as suas "más tendências" e se tornando até superior aos homens por isso: aqui entra o importante papel de Madalena no contexto religioso medieval. Multiplicam-se no período da Patrística os escritos sobre as santas mulheres que foram mártires e virgens, com feitos grandiosos em nome do Cristo Triunfante então difundido na época. Isso tudo ao mesmo tempo em que se via o sexo feminino como um retrato da falsa lógica, um sofisma, que derrota tanto a gramática quanto a dialética, ciências tidas como as da verdade - a mulher era incontrolável, não-confiável, apelativa e até enganadora dos sentidos: note-se que Eva convence Adão a comer do fruto proibido através de suas palavras (Ibidem). Dessa forma, justapostas às inúmeras imprecações contra o sexo feminino engendradas pelos Padres da lgreja, encontrar-se-ão, facilmente, elogios a mulheres que foram santas: "encontram-se entre os Padres muitas descrições positivas de mulheres lado a lado com o retrato mais abstrato da feminilidade" (Idem, p.40). A transposição de tantos obstáculos para a santificação poderia fazê-la até mais santa que o homem: é a mulher no "entre", humanizada, porém dentro das devidas delimitações, isso atrai as mulheres pela possibilidade de ascese. Em outras palavras: A virtude mariana e da "heróica" superação feminina acaba sendo um pólo de atração às mulheres no cristianismo primitivo:

\footnotetext{
Não só é a mulher que é salva mais santamente do que seu congênere masculino, mas também é uma mulher que carrega a possibilidade de salvação. Maria, a redentora de Eva que a liberta da maldição da Queda, é um dos grandes temas da era formadora cristã e um esteio da atração do cristianismo (Ibidem).
}

É imperativo estabelecer preponderante diferença entre a misoginia cristã e a misoginia clássica (pagã, Greco-romana). Diferenciam-se, basicamente, por ser a primeira "teologizada", isto é, pensadas, fundadas, nas premissas de uma interpretação fundamentalista dos textos bíblicos. 
As conseqüências da misoginia teologizada praticada e apregoada na época patrística terá sérias conseqüências para a Idade Medieval que estava por nascer. Não só contribuirá, significativamente, para a formação das mentalidades deste período, mas para a contrução dos topoi antagônicos, que farão presença simultânea no medievo e causarão a marginalização e uma opressão ostensiva do sexo feminino, como padrão comportamental reflexivo do teocentrismo imperante.

\begin{abstract}
A atitude cristã simultaneamente bivalente torna o feminino tão abstrato que a mulher (não as mulheres) só pode ser concebida como uma idéia e não como um ser humano. Ela polariza a definição do feminino a tal ponto que as mulheres são empurradas para as margens, excluídas do meio (...) afastadas da história. Novamente, isto não é para negar a importância de mulheres individuais no âmbito da Igreja Primitiva, ou a importância de mulheres místicas no final da Idade Média (Ibidem).
\end{abstract}

Tendo em vista todas estas considerações, constata-se que a visão medieval do gênero feminino terá raiz em muitas tradições pregressas, mas principalmente na patrística. Não só a misoginia medieval como a idealização da mulher, que se dará na Europa Medieval tanto pelo culto mariano como pelo amor cortês, tendências cujas características influenciarão fortemente a sociedade da Contra-Reforma, no século XVIII, inclusive nas colônias em que os jesuítas foram os evangelizadores, como o Brasil, por exemplo.

Quanto ao misoginismo dentro dos umbrais eclesiáticos, vemos que há muito já vinha sendo gestado no seio da Mater Ecclesiae, e vai ao encontro dos anseios do "dominador", do "repressor" - membro do clero ou não, quem legitima determinada ideologia é toda uma sociedade, não só um órgão dela numa incansável tentativa de erradicar de vez o substrato pagão e estabelecerse como única autoridade religiosa na ldade Média, posto que, numa lógica de pensamento, era a própria lgreja quem ganharia mais com isso: "segundo Bakhtin, esta visão de mundo, elaborada no correr dos séculos pela cultura popular, se contrapõe, sobretudo na Idade Média, ao dogmatismo e severidade da cultura das classes dominantes" (GINZBURG, 1987, p.187).

É imperativo salientar que as áreas culturais acabam por entrecruzar-se. Franco Jr. denomina tal fenômeno de "reequilíbrio da Idade Média Central" (FRANCO JR, 2006, p. 121): "com as acentuadas transformações sociais, políticas, e econômicas ocorridas a partir do século $\mathrm{XI}$, foi quebrada a clara 
predominância desfrutada pela cultura clerical na fase anterior. A cultura vulgar ressurgia com força". Deste encontro, a cultura intermediária sofre a influência de ambas as áreas culturais: o "Renascimento do século XII (...) significou a recuperação e revalorização da cultura Greco-Latina [cultura erudita], mas também, ao mesmo tempo a reemergência de uma cultura folclórica" (Idem, p. 122), ou seja, "não é globalmente expressão da cultura erudita, e sim da cultura intermediária" (Ibidem). É assim que neste tipo de literatura, provindas da classe intermediária, podemos notar elementos da ideologia clerical e de "reação" folclórica, concomitantemente.

A "Reação Folclórica" do século XI será duramente sufocada pela intervenção do duplo lgreja-Classes Dominantes. A já citada Supper Illus Specula é promulgada no século XIV, por João XXII, postulando verdadeiro entrave e condenação a qualquer prática religiosa ligada à magia ritual, ou costumes pagãos, o que acontecia, principalmente, na cultura subalterna ${ }^{8}$; práticas, estas, que sempre existiram no folclore - ritos de fertilidade, culto de Jano, oferendas nas fontes -, tudo foi estigmatizado como "pactos com demônio"; e, em 1398, a Universidade de Paris corroborou todas estas premissas e aderiu à posição papal (MALEVAL, 2004, p. 69). É importante destacar a assertiva de Rose Marie Muraro, quando falamos de toda uma classe dominante coadunada no processo inquisitorial, sem eximir a principal gestora do acontecimento, a lgreja, de qualquer "culpa": "os quatro séculos de perseguição às bruxas e aos heréticos nada tinham de histeria coletiva, mas, ao contrário foi uma perseguição muito bem calculada e planejada pelas classes dominantes, para chegar à maior centralização do poder" (MURARO, 2000, p.78).

O campo estava semeado e germinando para o que haveria de vir:

Por exemplo, com base em arquivos judiciais foram documentados 288 casos de bruxaria no Norte da França entre meados do século XIV e finais do XVII, numa proporção de 82 mulheres para 100 casos (apud SALLMAN, 1992). No século XV, a perseguição das bruxas chegaria ao seu apogeu, ocorrendo o auge das fogueiras entre 145560 e 1480-85 [já Idade Moderna] (MALEVAL, 2004, p. 71).

Ao levar-se em conta o período inquisitorial, deparamo-nos com o interessante conceito de "Sociedade Repressora", que como um gatilho

\footnotetext{
${ }^{8}$ Daí o principal alvo dos Tribunais serem, além das mulheres, pessoas pertencentes à cultura subalterna.
} 
desencadeador de acontecimentos de flagrante opressão pública e luta contra os chamados hereges, é um postulado do medievalista Robert Moore (MOORE, 1989, s.p.). Tal assertiva encaixa-se de forma muito plausível na forma de abordagem que Dias Gomes adota para o tema de o Santo Inquérito. Essa compleição de conformidade é dada, na peça, sob a representação do alarido popular que acompanha algumas cenas em rubricas, ou seja, o som seria um sema dessa participação de toda uma "Sociedade Repressora". Segundo a teoria de Moore (1989, s.p.), as Cruzadas (1095) e a Inquisição (implantação entre 1184-1229) teriam a tácita aceitação de várias camadas populares, não sendo somente atitude isolada de só uma instituição, mas da realeza, dos nobres feudais, dos clérigos, do campesinato (populares e pequenos comerciantes), da justiça, dos soldados e, principalmente, do "braço secular" que era quem aplicava as penas: o papel da lgreja era acusar os hereges. Há de se levar em conta fatores como a contribuição da clericalização aguda, vigente nos séculos XII-XIII-XIV (Idade Média Central), produto de um contexto de pós-reforma gregoriana, com um lançar de raízes da "Institucionalização da lgreja", conforme o supramencionado. É quando a chamada "Sociedade Repressora" (MOORE, 1989, s.p.), estabelece-se sócioculturalmente de forma mais "aguerrida". Fomentando, além da Inquisição (1184-1229), também as Cruzadas, que se tornam realidade de embate político e cultural desde 1095 (Concilio de Clermont).

Com os movimentos de Reforma e Contra-Reforma, estas características já agudas no Tardo-Medievo, levaram ao genocídio promovido pelo Santo Ofício: uma matança geral, que atingia não só os hereges, mas também os judeus. Especialmente em Portugal a prática de judaísmo tornou grave crime na Idade Moderna, prolongando-se também às colônias, inclusive ao Brasil, que é onde se passa a ação d' O Santo Inquérito.

Os jesuítas, responsáveis pela inquisição brasileira, juntamente com os dominicanos aqui desembarcam em busca de crimes contra a fé e a coroa, especialmente no período em que se passa a ação da peça de Gomes e a narrativa que é sua raiz (folclore paraibano). Em Portugal, apesar de já estarmos em um período pós-Restauração, ainda se faziam sentir os efeitos da religião repressora promovida pela União lbérica, com a mão poderosa da 
cristianíssima monarquia espanhola e a aguerrida perseguição aos inimigos da Igreja Romana, tidos como inimigos do Estado.

Levando em conta o conceito de "Sociedade Repressora" de Moore (op. cit.), outra representação dessa aceitação tácita de uma realidade opressora emerge, seria a personagem de Simão Dias, o exato antônimo de Augusto Coutinho. O pai de Branca poderia ter salvado o noivo da moça com um simples mover de dedos, mas por medo do Santo Ofício não o faz, permitindo seu assassinato em um instrumento de tortura.

SIMÃO

Estou vivo, pelo menos. E é isso que importa, não acha?

(...)

SIMÃO

É uma loucura pensar que, num momento desses, se possa salvar alguma coisa além da vida. Desde o primeiro momento compreendi que devia aceitar tudo, confessar tudo, declarar-me arrependido de tudo. Vamos nós discutir com eles, lutar contra eles? Tolice. Têm a força, a lei, Deus e a milícia - tudo do lado deles. Que podemos nós fazer? De que adianta alegar inocência, protestar contra uma injustiça? Eles provam o que quiserem contra nós e nós não conseguiremos provar nada em nossa defesa. Bravatas? Também não adiantam. Eu vi o que aconteceu com Augusto.

(...)

\section{SIMÃO}

Em primeiro lugar, o homem tem a obrigação de sobreviver, a qualquer preço; depois é que vem a dignidade. De que vale agora para nós, para os pais dele, para você, para ele mesmo, essa dignidade?

(...)

SIMÃO

(Faz uma pausa. As palavras custam a sair.) Ele não resistiu... BRANCA

(Num sussurro.) Morreu! (Mais forte.) Eles o mataram! (Seus joelhos vergam, repete baixinho.) Eles o mataram... Eles o mataram...

SIMÃO

Eu sabia que ele não ia resistir. Estava vendo!... depois de tudo, ainda o penduraram no teto com pesos nos pés e o deixaram lá... Quando os guardas voltaram, ainda tentaram reanimá-lo, mas...

BRANCA

(Sua dor se traduz por um imenso silêncio. Subitamente:) E o senhor não podia ter feito nada?!

(...)

SIMÃO

Pensei em baixar a corda. Mas...

(...)

SIMÃO

$\mathrm{E}$ o que me custaria esse gesto? Um homem deve pesar bem suas atitudes, e não agir ao primeiro impulso. Eu podia ter tido o mesmo destino que ele. Era ou não era muito pior?

(GOMES, 1985, 137-139) (GRIFOS NOSSOS) 
Toda a realidade que a "Sociedade Repressora" da lbéria produz, renova-se no século XVIII, tanto nas colônias quanto na metrópole. Dias Gomes comenta um pouco de sua pesquisa, discutindo o tríptico teatrofolclore-história.

Padre Bernardo era jesuíta, muito embora os inquisidores fossem, em geral, dominicanos. Mas, nas visitações ordenadas para o Brasil, os jesuítas tiveram papel de destaque, vindo a ser, depois, suas maiores vítimas, com a perseguição a eles movida pelo Marquês de Pombal. Além disso, aqui, como em toda a peça, seguimos a lenda, procurando harmonizá-la, sempre que possível, com a verdade histórica e subordinando ambas aos interesses maiores da obra dramática.(GOMES, 1985, p.21)

A Inquisição no Brasil é evocada para discutir a realidade em que Gomes vive no Brasil de 1966, o que confirma a assertiva de Ubersfeld (2005, p.71): "não existe leitura nem encenação inocente". (UBERSFELD, 2005, p.71) (grifo nosso)

\section{Branca Dias e seus semas}

A personagem Branca Dias tem a sua ascendência no folclore paraibano. Os seus caracteres são ampliados e revistos pelo autor Dias Gomes, ornando todo o mito com sua criação "cosmo-artística". Gomes focaliza a personagem em seu lado "humano", tirando-a do universo maravilhoso popular, fantasmagórico e folclórico. Branca é transplantada do "causo" à beira da fogueira para um universo mais humanístico, na busca do mimético: heroína dos palcos. Sobre a personagem teatral cabe comentar juntamente com Ubersfeld:

Na medida em que o texto teatral é essencialmente não-linear, mas tabular, a personagem é um elemento decisivo da verticalidade do texto: é ela que permite unificar a dispersão dos signos simultâneos. A personagem retrata, então, no espaço textual, o ponto de cruzamento ou, mais exatamente, de repercussão do paradigma sobre o sintagma; ela é um lugar propriamente poético. No campo da representação, ela surge como o ponto de ancoragem em que se unifica a diversidade dos signos. (...) A noção de personagem (textual-cênica), em sua relação com o texto e com a representação, é uma noção da qual a semiologia do teatro não pode abster-se. (UBERSFELD, 2005, p.72)

Sobre a personagem ainda é necessário dizer: Branca Dias funciona como elemento agregador e unificador de todo um feixe signatário, de um 
grupo de semas que sem a sua persona estariam apartados. Aqui entra 0 importante papel de uma abordagem semiológica do texto teatral:

O trabalho de uma semiologia da personagem é mostrá-la justamente como divisível, permutável: ao mesmo tempo articulada em elementos e, ela mesma, elemento de um ou mais conjuntos paradigmáticos (...). A personagem é um agregado complexo reunido sob a unidade de um nome. (UBERSFELD, 2005, p. 73)

\section{Os feixes signatários em Branca Dias e os loca adjacentes}

O nome Branca, per se, já evoca uma pureza da qual a protagonista é portadora. Possui a carga semântica, a significação da cor. A personagem possui esta pureza, numa perspectiva dialógica com os componentes que a circundam, podendo-se enxergar pelas ações e reações de Branca uma amoralidade muito própria do naturalismo pagão. $O$ que parece muito natural a ela, configura-se em pecado mortal para aqueles que tem por função condenála, confundi-la e acusá-la:

\section{BRANCA}

(Mostra-se perturbada com a acusação.) Heresia... Atos contra a moralidade... Talvez essas palavras tenham outra significação para os senhores. Pelo que eu entendo que querem dizer, não posso, de modo algum, aceitar a acusação (GOMES, 1996, p. 34).

Em toda a duração do julgamento, o texto indica patente polarização entre o naturalismo amoral de Branca (tendo por referentes preceitos ideológicos teocêntrico-fundamentalistas) e a ideologia judaico-cristã inquisitorial, carregada de preconceitos e de uma retórica jurídica voltada para a condenação da protagonista. O trecho a seguir ilustra tal fato, demonstrando que, o que aos olhos de Branca é um simples banho, e sua nudez natural para ela, torna-se pecado mortal e ofensa contra o deus do Santo Ofício:

\section{PADRE BERNARDO}

Aqui estamos, senhores, para dar início ao processo. Os que invocam os direitos do homem acabam por negar os direitos da fé e os direitos de Deus, esquecendo-se de que aqueles que trazem em si a verdade têm o dever sagrado de estendê-la a todos, eliminando os que querem subvertê-la, pois quem tem o direito de mandar tem também o direito de punir. É muito fácil apresentar esta moça como um anjo de candura e a nós como bestas sanguinárias. Nós que tudo fizemos para salvá-la, para arrancar o Demônio de seu corpo. E se não conseguimos, se ela não quis separar-se dele, de Satanás, temos ou não o direito de castigá-la? Devemos deixar que continue a propagar heresias, perturbando a ordem pública e semeando os germes da anarquia, minando os alicerces da civilização que construímos, a civilização cristã? Não vamos esquecer que, se as heresias 
triunfassem, seríamos todos varridos! Todos! Eles não teriam conosco a piedade que reclamam de nós! $E$ é a piedade que nos move a abrir este inquérito contra ela e a indiciá-la. Apresentaremos inúmeras provas que temos contra a acusada. Mas uma é evidente, está à vista de todos: ela está nua!

BRANCA

(Desce até o primeiro plano.) Não é verdade!

PADRE BERNARDO

Desavergonhadamente nua!

BRANCA

Vejam, senhores, vejam que não é verdade! Trago as minhas roupas, como todo o mundo. Ele é que não as enxerga!

Padre sai, horrorizado.

BRANCA

Meu Deus, que hei de fazer para que vejam que estou vestida? É verdade que uma vez - numa noite de muito calor - eu fui banharme no rio... e estava nua. Mas foi uma vez. Uma vez somente e ninguém viu, nem mesmo as guriatãs que dormiam no alto dos jeribás! Será por isso que eles dizem que eu ofendi gravemente a Deus? Ora, o senhor Deus e os senhores santos têm mais o que fazer que espiar moças tomando banho altas horas da noite. Não, não é só por isso que eles me perseguem e me torturam. Eu não entendo... Eles não dizem... só acusam, acusam! E fazem perguntas, tantas perguntas!

(GOMES, 1996, p. 31-32) (GRIFO NOSSO)

Aqui, é importante ressaltar o sema da rubrica "Desce até o primeiro plano." (id.) demonstrando atitude firme de Branca Dias ao se defender. Daí analisa-se a importância das didascálias, do gesto do actante e do diálogo para o teatro, que funciona como um feixe de signos, que jungidos formam as significantes dramatúrgicas.

O que é um texto de teatro? Ele é composto de duas partes distintas, mas indissociáveis: o diálogo e as didascálias (ou indicações cênicas ou direção de cena). A relação textual diálogo-didascálias é variável de acordo com as épocas da história do teatro. Às vezes inexistentes ou quase (mas plenas de significação quando existem) as didascálias podem ocupar um espaço enorme no teatro contemporâneo.

(UBERSFELD, 2005, p.6)

Esta pequena digressão nos permite avaliar semiologicamente todo um conjunto de teorias sobre a questão do gesto determinado pelas didascálias, muito claras no texto de Dias Gomes, que já abordamos num outro tópico do presente estudo. Aqui expõe-se a premissa de Tadeusz Kowzan (2006, p.106) em A Semiologia do Teatro sobre o movimento cênico do actante e o signo:

O gesto constitui, depois da palavra (e sua forma escrita) o meio mais rico e maleável de exprimir os pensamentos, isto é, o sistema de signos mais desenvolvido. (...) $O$ terceiro sistema de signos cinestésicos compreende deslocamentos do ator e suas posiçoes no espaço cênico. É principalmente uma questão de: - lugares 
sucessivos ocupados em relação aos outros atores, aos acessórios, aos elementos do cenário [vd. primeira rubrica da peça], aos espectadores; (...) Estas categorias principais do movimento cênico do ator, consideradas do ponto de vista semiológico, são suscetíveis de prover-nos os mais variados signos.

(KOWZAN, 2006, p.106)

Retornando à mundivisão de Branca Dias, pode-se entrever que esta reflete uma naturalidade, principalmente a respeito do amor, das coisas simples da vida. Para Branca, tudo seria um dom provindo do Divino, não poderia haver pecado em desfrutar da Criação. A amoralidade de Branca Dias é exposta através de seu discurso, sua visão de Deus é libertária e desprendida de uma visão pétrea e institucionalizada:

Deus deve passar muito mais tempo na minha roça, entre as minhas cabras e o canavial batido pelo sol e pelo vento, do que nos corredores sombrios do Colégio dos Jesuítas. Deus deve estar onde há mais claridade, penso eu. E deve gostar de ver as criaturas livres como Ele as fez, usando e gozando essa liberdade, porque foi assim que nasceram e assim devem viver. Tudo isso que estou lhes dizendo, é na esperança de que vocês entendam... Porque eles, eles não entendem... Vão dizer que sou uma herege e que estou possuída pelo Demônio. E isso não é verdade! Não acreditem! Se o Demônio estivesse em meu corpo, não teria deixado que eu me atirasse ao rio para salvar Padre Bernardo, quando a canoa virou com ele!...

(GOMES, 1996, p.33)

Por exemplo, o signo "tomar banho na madrugada" que, para a protagonista, é uma necessidade natural, a fim aliviar o calor de uma noite quente. Para os inquisidores é signo de malleficium, isto é, ato de bruxaria, próprio de mulheres que copulam com o demônio (SPRENGER; KRAMER, 1991).

\begin{abstract}
BRANCA
Não sei, não sei, não sei... Oh, a minha cabeça... Por que me fazem todas essas perguntas, por que me torturam? Eu sou uma boa moça, cristã, temente a Deus. Meu pai me ensinou a doutrina e eu procuro segui-la. Mas acho que isso não é o mais importante. O mais importante é que eu sinto a presença de Deus em todas as coisas que me dão prazer. No vento que me fustiga os cabelos, quando ando a cavalo. Na água do rio, que me acaricia o corpo, quando vou me banhar.
\end{abstract}

(GOMES, 1996, p.33)

Um dos fatores mais preponderantes para a condenação de Branca é a sua transgressão quanto ao Eros, isto é, a sua sexualidade pronunciada e declarada, sem qualquer máscara ou pretenso fingimento. Poderíamos dizer que aos ouvidos dos inquisidores isso soaria como uma verdadeira declaração 
de culpa. Era uma legítima portadora da luxúria, da vaidade, da gula e de outros pecados capitais, inscrevendo-se, como foi ilustrado na mundivisão clerical tardo-medieva: é uma completa guerra de discursos completamente opostos - "a personagem pode estar integrada em um discurso que é o discurso textual integral, em que ela figura como elemento retórico" (UBERSFELD, 2005, p.76):

\begin{abstract}
BRANCA
No corpo de Augusto, quando roça no meu, como sem querer. Ou num bom prato de carne-seca, bem apimentado, com muita farofa, desses que fazem a gente chorar de gosto. Pois Deus está em tudo isso. E amar a Deus é amar as coisas que Ele fez para o nosso prazer. É verdade que Deus também fez coisas para o nosso sofrimento. Mas foi para que também 0 temêssemos e aprendêssemos a dar valor às coisas boas.
\end{abstract}

(GOMES, 1996, p.33)

Quando Padre Bernardo adentra no cenário, tudo é invertido. Ele é o elemento desestabilizador. A pureza de Branca subverte-se. Em sua confusão, nessa tentativa de mudar o pensamento e mundivisão da protagonista, o Padre faz com que a culpabilização pese sobre o mais fraco (a própria Branca) (MURARO, 2000) e sobre os elementos, antes enxergados com naturalidade por Branca. A ponto de deixar-se confundir pelos aparelhos repressores vigentes: cruéis, opressores e punitivos.

Ela, que era um signo da "pureza original", deixa-se convencer, durante certo tempo, por uma visão distorcida de mundo, justamente, por essa simplicidade e fé pura que possuía. Todavia, no fim, a natura prevalece (cf. primeira citação). Como no livro bíblico do Genesis ao deixar-se influenciar pelo veneno ofídio de Bernardo passa a tapar-se, envergonhar-se de si, assim como o par Adão e Eva, metáforas do homem em suas dimensões, cobrem a nudez diante do Deus-Irado do Antigo Testamento (Ave Maria, s.d., p. 51). Branca em uma fase intermediária passa a esquivar-se de si mesma, de sua própria natureza.

Bernardo reveste-se da simbologia primeira do Barroquismo, do homem em conflito com essa pureza, com essa limpidez, com sua natureza original. Ele é o signo "diabólico", isto é, divisor, desestabilizador do equilíbrio antes existente; rompimento da unicidade existente antes de sua chegada. É o dualismo que oprime, massacra, para que, destruindo Branca, objeto do seu 
desejo sexual latente, sugerido ao longo da obra e revelado no desfecho, também seja aniquilado.

\section{BRANCA}

Vamos lá em casa, o senhor tira a batina e eu ponho pra secar.

Posso lhe arranjar uma roupa de meu pai, enquanto o senhor espera.

PADRE

(A proposta parece assumir para ele uns aspectos de tentação.) Não... Isso não é direito...

(GOMES, 1996, p.35)

Aniquila o objeto, para que a natureza também seja aniquilada. A morte de Branca representa uma busca cruel de "cobrir-se", eclipsar seus desejos mais primais despertados pela inocente Branca. A condenação de Branca é como uma imagem figurativa do "falo extirpado".

\section{BRANCA}

Eu sei. E sei também que não sou a primeira. E nem serei a última.

Os guardas entram e amarram-na pelos pulsos e pelo pescoço com cordas e baraço, e a arrastam assim por uma rampa para o plano superior, onde surgem os reflexos avermelhados da fogueira. Padre Bernardo, no plano inferior, a vê, angustiado, contorcer-se entre as chamas. Contorce-se também, como se sentisse na própria carne. Um clamor uníssono, a princípio de uma ou duas vozes, às quais vão se juntando, uma a uma, as vozes de todos os atores, em crescendo, até atingirem o limite máximo, quando cessam de súbito.

\section{PADRE}

(Caindo de joelhos.) Finalmente, Senhor, finalmente posso aspirar ao Vosso perdão!

(GOMES, 1985, p.143)

Numa outra clivagem interpretativa, os semas da luta libertária ficam claros na figura de Augusto, o noivo de Branca. Também através do nome da personagem de Augusto transparece o seu papel na tecitura dramatúrgica, considerando o seu significado, isto é, o que ele sugeriria numa camada inconsciente ao expectador: homem magnânimo, fiel aos seus valores mais intrínsecos. Proviria do étimo latino augustus, "adjetivo: augusto, sagrado, venerado; religioso" (Porto Latim-Português, 2005, p.52), mutatis mutandis, por flutuação semântica, este termo transplantado, adquire o significado de coisa venerável, respeitável, moralmente ilibada; sublime, majestosa (Aurélio, 2001). Branca torna-se esse reflexo dos atos de Augusto, isto é, dos ideais mais altos e nobres que ela alimenta em si. Tanto pela orientação cultural que o jovem advogado fornece quanto pela sua resignação diante das torturas do Santo 
Ofício, é obstinado em fazer o que é certo e não cede, sequer, ante as ameaças de morte. É ele quem a ensina a ler, dá livros a Branca, e um dos principais livros é a bíblia em português: o uso do vernáculo, das línguas romance foi uma grande questão no Tardo Medievo e na Idade Moderna, sinal herético até, (FALBEL, 2007), indicativo significante disso é o fato de uma das primeiras medidas do monge Martinho Lutero, fundador do protestantismo, foi traduzir da Bíblia do latim. Vem à baila a questão do conhecimento e da mulher: a misoginia clerical (DUBY, 2001). Já cultivada por boa parte do estamento dos clérigos na Idade Média Central e Baixa Idade Média, acentuase a partir da Contra-Reforma conforme o explicado (cf. o tópico Inquisição).

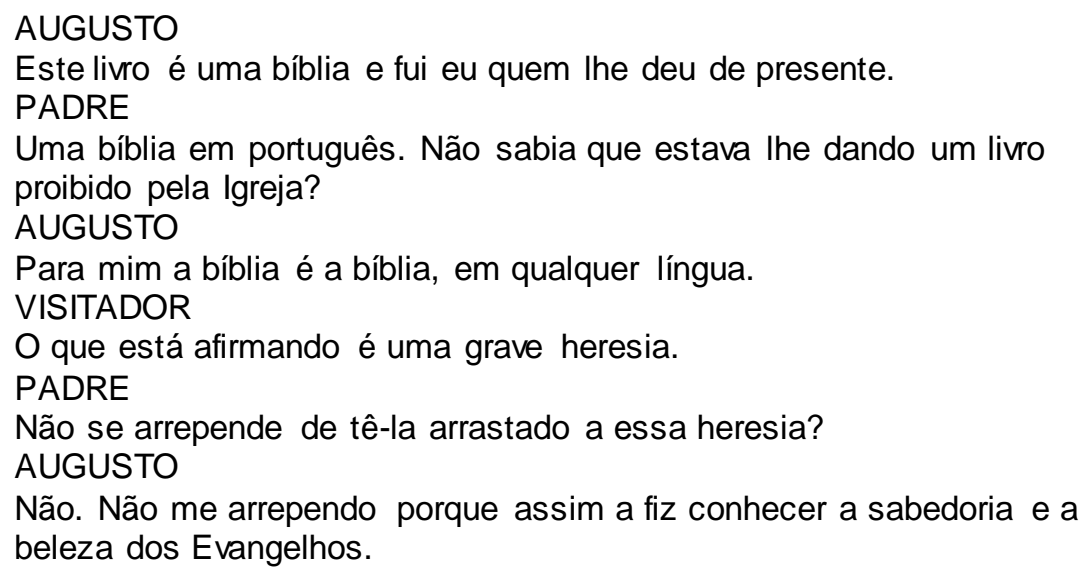

(GOMES, 1985, p. 117)

Ainda em outro trecho, como no anterior, o medo do conhecimento feminino mostra-se como flagrante crime, digno de ser até chamado de heresia. Aqui Branca toma uma postura questionadora inaceitável em qualquer sociedade homogeneizadora e sob o julgo de uma férrea mão totalitária:

BRANCA

Por que nunca aceitam moças nos colégios?

PADRE

Porque moças não precisam estudar.

BRANCA

Nem mesmo ler e escrever?

PADRE

Isso se aprende em casa, quando se quer e os pais consentem.

BRANCA

(Com certo orgulho.) Eu aprendi. Sei ler e escrever. E Augusto diz que faço ambas as coisas melhor do que qualquer escrivão de ofício.

PADRE

Quem é Augusto?

BRANCA

Meu noivo. Foi ele quem me ensinou. Mas foi preciso que eu insistisse muito e quase brigasse com meu pai. É tão bom.

PADRE

Ler? 
Neste trecho, fica patente a discordância de Padre Bernardo, ícone de uma Igreja Repressora, e o início de seu ódio por Augusto, como se este fosse o instrumento de destruição da pureza de Branca, o intruso em um Éden que teria por locus o seu próprio corpo: o paradoxo do feminino, entre o paraíso e o inferno - Augusto apresentar-se-ia como o réptil maligno que seduz Eva (cf. Ave Maria, s.d., p. 51).

Todos os circundantes devem ser levados em conta, como se busca empreender no presente estudo, assim, salienta-se que outro fator significativo, quanto às personagens, é o fato de os inquisidores não serem nomeados: são designados por sua função no Inquérito: visitador, notário, padres; como se sua função os definisse como pessoas, rotulados, inexoravelmente rotulados: somente capas a serviço de um sistema, sem alma ou coração (emoções): "a personagem pode ser a metonímia ou a sinédoque (...) de um conjunto paradigmático, ou a metonímia de uma ou várias outras personagens" (UBERSFELD, 2005, p. 76). UBERSFELD complementa, ainda:

\begin{abstract}
A personagem textual, tal como se mostra na leitura, nunca está completamente isolada: apresenta-se rodeada de um conjunto de discursos a respeito dela, discursos estes infinitamente variados conforme a história desse ou daquele texto (...)
\end{abstract}

(UBERSFELD, 2005, p. 70).

\title{
6. OS FEIXES SIGNATÁRIOS DE BRANCA DIAS EM PERSPECTIVA RELACIONAL COM O DIVINO
}

Conforme o supramencionado, Branca Dias possui uma relação muito naturalista com o divino, o que é visto como um malleficium pelos inquisidores (SPRENGER; KRAMER, 1991) ou resquícios de um paganismo diabólico, reprimido na Idade Média conforme determina a supramencionada Super Illus Specula promulgada em 1320 que condenava, peremptoriamente, a magia ritual.

Sua imagem está longe de ser o de uma "santa", uma mártir, como se poderia presumir. Como já foi sobejamente mostrado, a personagem dista muito deste estigma, na imagética que uma legitima "filha do sagrado" teria para os inquisidores. Esta seria uma mulher desprovida de sua feminilidade, 
masculinizada, com ideais inalcançáveis e provida de uma espiritualidade descarnada que não passaria pelo humano para chegar ao divino, visão teológica moderna.

Todavia, pelos ideais subidos e heróicos, Branca se aproxima destas imagens que a hagiografia até hoje indica como exemplos. Guardadas as devidas proporções diferenciais, Branca, muitas vezes, é aproximada a santa Joanna D'Arc, por ter sido martirizada pelo Santo Ofício, pela simplicidade desconcertante com que responde às perguntas capciosas dos maléficos inquisidores e pelo crime de que é acusada: heresia.

Branca é, simultaneamente, uma santa e uma mulher comum, sendo uma herege somente de acordo com a perspectiva doentia de fé, que os homens do Santo Ofício possuíam.

\begin{abstract}
VISITADOR
Já lhe demos todas. Acho que nos iludimos com ela desde o princípio. Sua obstinação e sua arrogância provam que tem absoluta consciência de seus atos. Não se trata de uma provinciana ingênua e desorientada; tem instrução, sabe ler e suas leituras mostram que seu espírito está minado por idéias exóticas. Declara-se ainda inocente porque quer impor-nos a sua heresia, como todos os de sua raça. Como todos os que pretendem enfraquecer a religião e a sociedade pela subversão e pela anarquia.
\end{abstract}

(GOMES, 1985, p.142)

Reitera-se que Branca Dias é uma figura lendária do folclore paraibano, dizendo-se que todos os dias, nas madrugadas, a sua alma vagaria até os subsolos do Convento de São Francisco, onde Augusto Coutinho, seu amor, estaria preso. Gomes a transplanta para a literatura de forma diferenciada, ela se aproxima do mito pelo amor imortal a Augusto. Dias Gomes corrobora a linha de pensamento aqui seguida: sintetiza tudo o que foi dito e detalha 0 posicionamento sobre a personagem de Augusto.

Diz a lenda que, em noites de plenilúnio, quando o nordeste sopra na copa das árvores, Branca desliza pelas rua silenciosas da capital paraibana $e$ vai visitar $o$ noivo prisioneiro e torturado nos subterrâneos do Convento de São Francisco. Um dos mais belos aspectos da estória é esse amor e a fidelidade a ele. Mas não é apenas o amor que tem por Branca o que leva Augusto a preferir a morte a acusá-la; é a certeza de que sua vida não vale a indignidade que querem obrigá-lo a cometer. Augusto é o homem em defesa de sua integridade moral, cônscio de que o ser humano tem em si mesmo algo de que não pode abrir mão, nem mesmo em troca da liberdade. Ele troca a vida pelo direito de vivê-la com grandeza, ao contrário de Simão. Neste, prevalece o sentimento de salvar-se a qualquer preço. Mesmo ao preço da própria dignidade. É a voz que 
não se levanta diante de uma injustiça praticada contra outrem, que não protesta contra uma violência, se essa violência não 0 atinge diretamente, esquecido de que as violências contra a criatura humana geram, quase sempre, uma reação em cadeia que talvez não pare no nosso vizinho. Seu receio de comprometer-se leva-o a assistir à morte de Augusto sem um gesto ou uma palavra em sua defesa. Essa omissão o torna cúmplice, como cúmplices são todos aqueles que se omitem por egoísmo ou covardia, podendo fazer valer a sua voz. Quem cala, de fato, colabora.

(GOMES, 1985, p.23)

Assim, poder-se-ia compreender que os signos indicam para uma leitura de Branca Dias mais como heroína romântica, com ideais humanistas bem definidos, um exemplum de luta libertária e amor firme e decidido, do que uma santa dentro dos paradigmas inquisitoriais.

Todavia as visões são conflitantes neste sentido. A visão sobre Branca Dias não tende a uma uniformização. Uns a vêem como uma "Joana D'Arc brasileira", outros como uma mulher forte e de "sangue quente", longe do estigma de uma santidade "tradicional", canônica, que a amputaria de sua plena feminilidade em todos os aspectos que o termo traz em seu bojo semântico.

\section{BRANCA}

Mas eu não quero ser santa. Minhas pretensões são bem mais modestas. Não é pela ambição que o Capeta há de me pegar. Quero viver uma vida comum, como a de todas as mulheres. Casar com o homem que amo e dar a ele todos os filhos que puder.

(GOMES, 1985, p.46)

Branca seria mais uma mulher apaixonada pela vida, sábia em sua simplicidade e na mundivisão da natureza. Encarna a própria Natura, o "terreno-não-pisado", quase o bon sauvage de Rousseau, que presa acima de tudo a vida em todas as suas pulsantes variadas e multicoloridas expressões.

\section{BRANCA}

Sabe as coisas que mais me divertem? Ler estórias e acompanhar procissão de formigas. Sério. Tanto nos livros como nas formigas a gente descobre o mundo. Quando eu era menina, conhecia todos os formigueiros do engenho. O capataz botava veneno na boca dos buracos e eu saía de noite, de panela em panela, limpando tudo. Depois ia dormir satisfeita por ter salvo milhares de vidas.

\section{BRANCA}

(GOMES, 1985, p.113)

Mas senhores, eu não pretendi nada disso! Nunca pensei senão em viver conforme a minha natureza e o meu entendimento, amando Deus à minha maneira; nunca quis destruir nada, nem fazer mal algum a ninguém! 
Sobre a Sexualidade e a Nudez, traços inexoráveis da luxúria própria do feminino, da vaidade e maldade de Eva consonante com o discurso clerical. $O$ sema discursivo ainda revela que a relação de Branca com Augusto é natural e o afloramento de articulação feminino/masculino perfeitamente comum em sua mentalidade, não haveria pecado em amar - justamente o oposto do que ideologia clerical fundamentalista apregoava:

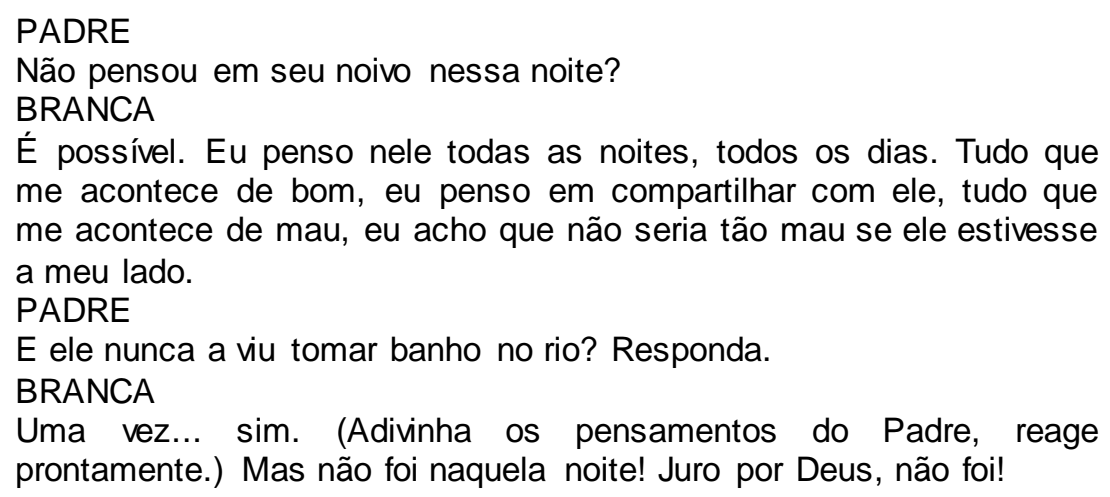
me acontece de bom, eu penso em compartilhar com ele, tudo que me acontece de mau, eu acho que não seria tão mau se ele estivesse a meu lado.

PADRE

E ele nunca a viu tomar banho no rio? Responda.

BRANCA

Uma vez... sim. (Adivinha os pensamentos do Padre, reage prontamente.) Mas não foi naquela noite! Juro por Deus, não foi!

(GOMES, 1985, p.48/49)

Há uma clara batalha de discursos: a linguagem dos inquisidores não é a linguagem de Branca Dias. A personagem encarna o que UBERSFELD enuncia da seguinte maneira:

\begin{abstract}
A personagem pode aparecer como aquela figura peculiar do discurso, figura fundadora da teatralidade, figura essencial e essencialmente 'dialógica', que é o oximoro (coexistência, no mesmo lugar do discurso, de categorias contraditórias: vida-morte, luz-noite, lei-crime). (UBERSFELD, 2005, p.78)
\end{abstract}

A mundivisão diametralmente oposta entre ambas as ideologias fica patente: representa uma hercúlea luta atemporal "contra um esmagador poder deturpador de valores" (MICHALSKI, 1985, p.12). Sobre isso salienta-se a opinião de Baccega, em Palavra e Discurso, no que concerne à linguagem e significação:

Para se enfrentar a questão dos discursos, temos, portanto, de considerar que a linguagem não é meramente um exercício de significações circunscritas individualmente, delimitadas "no" indivíduo. Há que se perceber o "deslocamento" dessas significações: a produção do sentido está na sociedade, está na história.

(BACCEGA, 2000, p.27) 
Observa-se que a oposição de semas discursivos entre Branca e o "Poder Esmagador Inquisitorial", dá-se no campo ideológico em vistas do que o autor deseja representar: a situação da repressão militar - "a 'personagem' não apenas ocupa o espaço de todas as incertezas textuais e metodológicas, como é o próprio lugar do embate" (UBERSFELD, 2005, p.69). Baccega (2000) estabelece, ainda, sobre a singular importância do discurso como sema e como a subversão da linguagem é principal recurso funcional para a repressão do indivíduo é o principal locus de enfrentamento:

\begin{abstract}
A palavra (...) só existe no intercâmbio da vida social. Ela "canta" sempre num salão de baile, onde "dança conforme a música", utilizase de máscaras ou despe-se (...) a palavra nunca está só (...). Ela está sempre num discurso (...) é no discurso que a palavra assume seu significado. (...) A Língua (...) é um todo dinâmico que abarca o movimento da sociedade: por isso é lugar de conflitos. Esses conflitos se concretizam nos discursos, Neles, as relações lingüísticas trazem inscritas as diferenças de interesse, as propostas de direções diversas para o mesmo processo histórico (...). Os discursos constituem um "sistema de relações de substituição, paráfrases, sinonímias, etc.", que resultam em configurações diversas para cada um deles.
\end{abstract}

(BACCEGA, 2000, pp. 46.48.51)

Tal citação reitera a premissa de Ubersfeld de que não existe uma "inocência" no processo criador do artista e que os discursos compõem um feixe de alta significância no estudo da semiologia do teatro (UBERSFELD, 2005).

Yan Michalski ${ }^{9}$, em prefácio para edição de O Santo Inquérito (1985, p.12), ressalta as similaridades entre a personagem Branca Dias e Zé do Burro, o protagonista de O Pagador de Promessas $^{10}$ (1960), tendo por fulcro comparativo, justamente a naturalidade com que perspectivação do divino é retratada em ambas as obras e o poder semiológico do discurso que envolve a ambos:

\begin{abstract}
Além desta trágica e obstinada luta contra um esmagador poder deturpador de valores, Zé-do-Burro e Branca têm em comum o seu admirável, simples e modesto humanismo. Ambos são cheios de vida, ambos têm uma espécie de solidez que lhes vem do íntimo trato diário com a terra e a natureza e ambos não pedem outra coisa senão viver com simplicidade, de acordo com os seus princípios, e cumprindo conscienciosamente a modesta e despretensiosa missão que acreditam ter recebido para cumprir na terra.
\end{abstract}

\footnotetext{
${ }^{9}$ Yan Michalski é renoma do teatrólogo brasileiro, contemporâneo de Dias Gomes.

${ }^{10}$ Tida por muitos críticos como a maior obra-prima de Dias Gomes, encenada em 1960 no TBC de São Paulo.
} 
(MICHALSKI, 1985, p.12-13)

A importância do discurso como sema é que dá essa apreensão interpretativa a Michalski, que é uma visão oposta a que Gomes possui de sua própria obra. Ryngaert corrobora: "Compreendemos melhor as dificuldades teóricas ligadas à personagem quando consideramos como uma verdadeira encruzilhada de diferentes discursos, como uma necessidade insubstituível e complexa da ficção teatral" (RYNGAERT, 1995, p.140). Ryngaert ainda levanta a seguinte assertiva sobre o sema do discurso, que complementa a perspectiva relacional com o divino e o locus discursivo que a personagem traz em seu bojo, é isso que desejamos salientar:

Quando constatamos literalmente o que a personagem faz (...), começamos a entrever que seu estatuto faz dela um agente da ação, um vetor que imanta desejos esparsos no texto, uma identidade fictícia por vezes apenas esboçada sob a qual se reúnem discursos. Não nos parece possível como uma força abstrata intercambiável em varias situações dramáticas típicas.

(RYNGAERT, 1995, p.138-139)

Enfim, a palavra ao autor. Para Gomes Branca seria despida dessa pretensa santidade da qual já falamos. O autor exprime o caminho de Branca em direção à fogueira da seguinte forma:

Branca é realmente culpada de heresia. De acordo com a monitoria do inquisidor-geral, instruções para a configuração das heresias, ela está "enquadrada" em vários artigos, sendo, além disso, acusada de atos contra a moralidade e da posse de livros proibidos. Mas, do princípio ao fim, ela caminha de coração aberto ao encontro de seu destino, acreditando que a sinceridade e a pureza que the moram no coração a absolvem de tudo. Mais importante do que conhecer e seguir as leis e os preceitos ao pé da letra não é estar possuída de bondade? Se ela traz Deus em si mesma, e se Deus é amor, isso não a redime inteiramente? E é isto, justamente, que a perde, não percebe que os homens que a julgam agem segundo uma idéia preconcebida, que subverte a verdade, embora eles também não tenham consciência disso e se considerem honestos e justos. E, sem dúvida, o são, se os considerarmos segundo seu ponto de vista. Branca nada percebe até o fim, quando já é tarde demais. Sua perplexidade cede lugar então a um princípio de consciência, que inicialmente a aniquila e depois a faz erguer-se na defesa fatal da própria dignidade. Branca nada tem de comum com Joana d'Arc, a não ser o fim trágico. Ela não é uma iluminada, não ouve vozes celestiais, nem se julga em estado de graça. É mulher. E para a mulher o amor é a verdadeira religião, o casamento a sua liturgia e o homem a humanização de Deus. Não se julga destinada a grandes feitos, nem a uma vida excepcional. Quer casar-se e ter quantos filhos puder - seu ventre anseia pela maternidade. Nada tem das maneiras masculinas de Joana, nem de seu espírito de sacrifício; é feminina, frágil e vê no prazer uma prova da existência de 
Deus. A grandeza que atinge, no final, ao enfrentar o martírio é dada pela sua recusa em acumpliciar-se com os assassinos de Augusto. É um gesto de protesto e também de desespero.

(GOMES, 1985, 20-21) (GRIFO NOSSO)

Tendo em vista tudo o que foi dito, é possível concluir que a perspectiva relacional de Branca com o divino é de comunhão com um naturalismo patente, sem a pecha de pecado e subversão da realidade que marca os veículos repressores de toda e qualquer época. Ao lado de Augusto, Branca alça lautos vôos, mais altos e belos sob a pena do grande artista que é Dias Gomes. Pelo artista, Branca Dias deixa de ser um fantasma e passa a ser uma heroína no mais legítimo sentido do termo, vista por diversas clivagens de inabalável coragem indubitável. Branca deixa de ser "assombração", se encarna pelo texto e arte de outro Dias. Sai do limbo e parte para o imaginário de todos que a lêem/ assistem:

A personagem de teatro é, no texto, um fantasma em busca de encarnação e, na representação, um corpo sempre usurpado, porque a imagem que nos é dada não é a única possível e jamais é completamente satisfatória. Em nossas leituras, sucede de nos abandonarmos a essa parte do sonho e construirmos ao mesmo tempo um invólucro sólido para apreendê-la.

(RYNGAERT, 1995, p. 141)

\section{CONSIDERAÇÕES FINAIS}

O Santo Inquérito é mais uma das obras primas de Dias Gomes. A sua genialidade fica impressa em Branca Dias como uma digital.

Os feixes semiológicos presentes em Branca atribuem universalidade à personagem, fazendo com que sua causa não se prende a tempos ou espaços definidos. Ela transcende qualquer dessas dimensões referenciais: é isso que só a arte por excelência é capaz de promover.

Em suma, pode-se dizer que dentro de Branca, como dentro da cor Branca podem-se encontrar inúmeros feixes de outros matizes, que lembram o ser humano de suas fraquezas, forças e até mesmo de sua própria perfídia.

Fica clara a seguinte afirmação: "O teatro (...) põe em jogo a própria totalidade da vida social e de suas instituições, permitindo captar nexos existentes entre a estética e a vida social, entre a criação artística e a trama da existência coletiva" (FLORENTINO, s.d., p. 2). 


\section{Referências Bibliográficas}

ABDALA JR., Benjamin. Introdução à análise da narrativa. São Paulo: Scipione, 2005.

BLOCH, Howard. Misoginia Medieval a Invenção do Amor Atual. São Paulo: 34, 1995.

CÂNDIDO, Antonio (et al.). A personagem de ficção. São Paulo: Perspectiva: 1968

DUBY, Georges; ARIÈS, Philippe (orgs.). História da vida privada: da Europa Feudal à Renascença. 7. ed. São Paulo: Companhia das Letras, 1995.

DUBY, Georges. Eva e os Padres. São Paulo: Companhia das Letras, 2001.

$$
\text { . Guerreiros e Camponeses. Lisboa: Estampa, } 1993 .
$$

FALBEL, Nachman. Heresias Medievais. São Paulo: Perspectiva, 2007.

FLORENTINO, Adilson. As relações do conhecimento no campo teatral: crônica de enfrentamento entre arte e ciência. In: IV Reunião Científica de Pesquisa e Pós Graduação em Artes Cênicas, s.d., Rio de Janeiro, UNIRIO.

FRANCO Jr., Hilário. Idade Média no Ocidente. São Paulo: Brasiliense, 2006.

GOMES, Dias. O Santo Inquérito. Rio de Janeiro: Ediouro, 1996.

. O Santo Inquérito. Rio de Janeiro: Civilização Brasileira, 1985.

O que sabemos e o que pensamos das personagens. In GOMES, Dias. O Santo Inquérito. Rio de Janeiro: Civilização Brasileira, 1985.

GONÇALVES, Francisco. A Imagem Precursora da Bruxa em A Demanda do Santo Graal. In: VEREDAS DA HISTÓRIA. Revista Eletrônica de Estudos Históricos, 2, Petrópolis, 2009. Disponível em <http://www.veredasdahistoria.com.br>.

GINZBURG, Carlo. O queijo e os vermes: o cotidiano e as idéias de um moleiro perseguido pela inquisição. São Paulo: Companhia das Letras, 1987.

GUINSBURG, J (et al.). Semiologia do Teatro. São Paulo: Perspectiva, 2006.

KOWZAN, Tadeusz. Os signos no Teatro in A Semiologia do Teatro. São Paulo: Perspectiva, 2006.

MALEVAL, Maria do Amparo. Representações diabolizadas da Mulher em Textos Medievais in DAVID, Sérgio Nazar (org.). As mulheres são o diabo. Rio de Janeiro: Eduerj, 2004.

MICHALSKY, Yan. Prefácio in GOMES, Dias. O Santo Inquérito. Rio de Janeiro: Ediouro, 1996.

MOORE, Robert. La Formación de Una Sociedad Represor: Poder y Disidencia en La Europa Occidental. Barcelona: Crítica, 1989. 
MURARO, Rose Marie. Textos da Fogueira. Brasilia: Letra Viva, 2000.

RYNGAERT, Jean-Pierre. Introdução a Análise do Teatro. São Paulo: Martins Fontes, 1995.

SILVA, Maria Célia. Branca a caminho da Fogueira: uma história se repete. In: Revista Espaço Acadêmico, 61, Rio de Janeiro, junho de 2006. Disponível em <http://www.espacoacademico.com.br>. Acesso em: 18/12/2010.

SCHMIDT, Arnaud. Introdução in GOMES, Dias. O Santo Inquérito. Rio de Janeiro: Civilização Brasileira, 1997.

SILVA, Andréia C. L. Frazão. Reflexões sobre o uso d categoria gênero nos estudos de História Medieval no Brasil (1990-2003) In: $<$ http://www.pem.ifcs.ufrj.br/GeneroBrasil.pdf>. Acesso em 22 DEZ 2008.

SPRENGER, James; KRAMER, Heinrich. Malleus Maleficarum - O Martelo das Bruxas. 7. ed. Rio de Janeiro: Rosa dos Tempos, 1991.

UBERSFELD, Anne. Para Ler o Teatro. São Paulo: Perspectiva: 2005 